\title{
RIGHTS IN REM ETC.- \\ A RESPONSE TO PROFESSOR GINOSSAR
}

This is a response, not a review. I shall therefore confine myself to the core of Professor Ginossar's theory.

There are three difficulties, or "riddles", which, according to Ginossar, remain to be solved. He formulates them thus:

1) How can a merely obligatory or personal right, being "relative", reach beyond the parties thereto and impose an obligation of noninterference on all people?

2) How is it that a real right over a thing belonging to someone else (for example, a mortgage or a right of way over another person's land), a right which is said to be "in the thing" and not a claim against any person, nevertheless casts upon the owner of the encumbered thing a burden more intimate and intense than the universal passive obligation of noninterference, even amounting on occasion to a duty to render active service (for example to maintain a fence in good repair)? This is presumably the fundamental "enigma of real rights".

3) Finally, how is it that the obligations which, according to Ginossar, bind the owner of the encumbered thing are transmitted to all succeeding owners, who thus become bound without having personally undertaken a liability-and this without the obligee's consent and by mere devolution of the encumbered thing?

Faced, in particular, with the challenge of the "enigma" of real rights, Ginossar boldly denies that such rights have existence as a separate species, and proposes to subsume them under the rubric of obligations. What are usually termed "real rights" are pronounced to be nothing of the sort. The heritage of the misconception of real rights should accordingly be partitioned between: (1) Property or Ownership (which Ginossar considers to form a class unto itself, quite apart from the other "real rights" that fall short of ownership), and (2) Obligation (créance), which will thus comprise, in addition to personal rights (such as claims in contract or tort), also all the "real rights" short of ownership.

To take Ginossar's first difficulty. It is true that one of the notable lines of legal development has been the expanding protection thrown around legitimate interests of all kinds, with the result that many obligations are in modern law almost as well protected as are rights of property. Yet the hard kernel of the difference survives. However extensive the protection cast around an obligatory right, such protection must relate, as does the right itself, to the person of the 
obligor. If, because of the obligor's conduct or misconduct, or because of an event that concerns him (such as his going insolvent, or dying or becoming insane or acquiring the status of an enemy alien or acquiring a counterclaim against the creditor) the obligatory right is terminated, then the right no longer can be interfered with by anyone-there is no longer anything to interfere with. There is thus always one person, the obligor, who occupies a crucial position in respect of the obligatory right.

There are also situations where the creditor is divested of his claim in circumstances where there is no illegality and where, consequently, no secondary remedial claim is acquired against the obligor to replace the primary claim that has been lost. Such, for example, is the case where the content of the obligation is performance of a service, and the obligor becomes incapacitated, through no fault of his, in body or in mind; and in other instances of force majeure. Extinction of the obligee's claim may or may not bring about the termination of an accessory obligation (if any) such as a guaranty. In any event, the guaranty must itself be tested as an obligation whereof the guarantor is obligor and the guaranty depends on him, as the principal obligation waits on the person of the principal obligor. Again, an obligatory claim is sometimes secured by mortgage, pledge, lien. Normally, the security will not survive extinction of the right secured. Assuming, however, that it survives, it is the security (a right in rem)-i.e. the mortgagee's or pledgee's title to seize or to hold something - that survives, not the obligation. The thing which is seized or held does not invariably belong to the obligor; it may have been lent by a friend to accommodate the borrower who needed a collateral. And it is clear that the lender of the thing, while he may eventually lose some wealth, is not anybody's debtor, not under obligation. Moreover, the collateral may or may not be sufficient in value to secure the obligation.

While an obligatory relationship may be "universal" in the sense that no one is permitted to interfere with it, the right is "relative" in the sense that it joins together two or more ascertained individuals on whom it impinges as on no other people. Just as a structure may be a bridge for those who are entitled to, and do, use it as such, while for all others it is a framework that must only be "respected" (not trespassed on, not destroyed), so a vinculum juris is a norm for the parties but only a datum for strangers.

Now to Ginossar's second perplexity. A real right differs from an obligatory right in that no person occupies with reference to it a position similar to that which is occupied by the obligor with reference to an obligatory right. Consider $\mathrm{A}$ who has a real right of way over land belonging to $\mathrm{B}$. Nothing that $B$ does, and also nothing that happens to B, can frustrate A's right. B can die, or he can go bankrupt, or he can sell or donate the land to some other person (including one who is not aware of the existence of the right) -in none of those eventualities will A's right of way be defeated. The mere existence of a right of way does not give $\mathrm{A}$ any claim on $\mathrm{B}$. A and B are 
legal strangers to one another. It may, of course, be otherwise when the right originates in a grant from $B$, in which case there may also be a contractual tie between $\mathrm{A}$ and $\mathrm{B}$. However, a right of way, including one originating in a grant, need not have any obligations attached to it, can be complete without such. B can of course violate A's right, as by preventing A from access to the land or by erecting a building which hinders exercise of the right. But B's duty to refrain from such misconduct is no more than the duty which lies on people in general. The common-law remedy for wrongful interference with easements is an action in tort for private nuisance-and the principles that govern the cause of action are the same where the defendant is a complete stranger as where he is the owner of the land.

It is true that disputes are more likely to arise between an encumbrancer and the owner of the land than between the encumbrancer and somebody who lives far away and has nothing to do with the land. There is a greater likelihood that the owner of the land would be tempted to interfere with the easement. It may well be that from his point of view it is the easement, rather than violation thereof, that looks like a nuisance. Psychological pressures, economic and other factors, may move him against the easement. But such differences between someone whose life passes in proximity to the right of way and the rest of mankind, who are less likely to be drawn into the orbit of tension generated by the existence of the right, are extraneous to the conception. The fact that the owner suffers does not mean that he owes.

I wonder whether Ginossar's bemusement with "the enigma of real rights" might not have a great deal to do with his literal acceptance of the phrase "a right in a thing which belongs to some other person" (jus in re aliena): This expression denotes that the thing "itself" belongs to one individual who "owns" it, and hence connotes that all other people are of necessity excluded from the thing "itself". From here on Ginossar's difficulty waxes: if all those other people are not blessed with the thing "itself", how is it possible to describe any right that they may have with reference to the thing, such as a right of way, a mortgage, a tenancy, as a real right, i.e. as an "immediate" right in the thing itself?

The "enigma", however, is solved as soon as we recall that the thing "itself" (a physical entity or a metaphysical concept) cannot strictly "belong" to anyone-not even to its so-called "owner". When you think of a plot of land over which one has a right of way, another a lease, and yet another the fee simple, the question who owns the land "itself" is, juridically, otiose. The person who has the "highest" right in the land (say: the fee simple held by free tenure) has a right, or rather a bundle of rights, with reference to the land-he cannot "reach" or "absorb" the land "itself". He may have more, and more important, and more "residual", rights than others have with reference to the land-even so, he has more of the same, of the abstract entity or juridical construct of "rights". And, indeed, even a practical statutory definition of the ownership of land or chattels, as the one adopted in the 
Land Law (1969) and in the Law of Chattels (1971) of Israel, proclaims ownership to be "the right to" hold, use, etc. The land "itself" is a matter perhaps of geology, but not of law. It defies and eludes the normative world of discourse, whose concern is not with things but only with rights to or over things-which is to say: only with human relations juridically viewed.

Contrary to what Ginossar maintains, I would say that the right of property or corporeal ownership cannot "absorb" the thing "itself" any more than other rights can; and is therefore not "radically different" from other real rights, and does not inhabit a plane loftier than that on which other rights dwell. Ginossar's exalted view of corporeal ownership leads him to the extraordinary proposition that corporeal ownership cannot itself be one of the real rights. In the course of elaborating what he believes to be the irreconcilable dissimilarity between "ownership" and "encumbrance", he says that "in ownership the property... is an asset in the hands of the owner, while on the contrary an encumbrance is for him a source of liability". (Cf. supra p. 335.) The plain point that for the encumbrancer his encumbrance is an asset must have been too obvious to be noticed.

If, as I maintain, no right can "absorb" the thing "itself", then the expression "a real right over property that belongs to someone else" should be taken with a grain of salt; and as the "owner" does not "absorb" the thing "itself", the thing "itself" continues to be available for the accommodation of other real rights as well, of rights which belong to people who are not "owners" of the thing "itself", and who are spoken of, more descriptively and conveniently than accurately, as having a real right "in some other person's property".

How, in what, does a real right differ from an obligatory right? The answer, known for many centuries, is that it differs from an obligatory right in that there is no obligation upon any ascertained person to correspond to the right; "sine respectu", as Grotius put it, "ad certam personam". Ginossar, however, is estopped by his theory from accepting this old learning. He argues in effect that as there can be no such thing as a right without a corresponding duty, there must be a duty somewhere to correspond to real rights as well. In fact, as we have seen, this leads him to the paradoxical idea that the "strongest" of the real rights-"la propriété"-is not a real right, there being no duty corresponding to it other than the universal passive duty of noninterference. Presumably, nevertheless, "la propriété" is some kind of right. But, then, if it is a right, the sufficiency of the universal passive duty to support rights is thereby demonstrated. Nevertheless, Ginossar is not prepared to accept any of this-precisely, it seems, because such acceptance would clevate all real rights to the exalted plane inhabited, according to him, only by the right of corporeal ownership or property (which, he believes, "absorbs" the thing itself). Thus, his a priori supposition that rights in re sua and rights in re aliena are too discrete to occupy the same niche in classification launches Professor Ginossar on a circular course. This is how that course 
runs: real rights, no less than other rights, require a corresponding duty-but the corresponding duty which they manifestly attract (viz. the universal passive duty of noninterference) "cannot" be the one which they require, this corresponding duty having been pre-empted in the service of corporeal ownership or property-and the latter, being so different from the lesser real rights, cannot be expected to allow the lesser real rights to join it in sharing the same corresponding duty.

There "must" therefore be a different duty. On whom will such a duty be made to rest? According to Ginossar, the duty is incumbent on the owner of the thing: if I have a right of way (or a life tenancy) over a field, then, Ginossar says, the owner of the field owes me a duty other than, and over and above, the universal passive duty of noninterference with my right which is imposed on all people. It will be noted that this stage of the argument is again fed by Ginossar's exalted image of corporeal ownership or property. In pursuance of his overstatement of the importance of "the owner of the thing itself", Ginossar attributes to him the corresponding duty. But why only to him? Are not lessees, mortgagees, etc. also burdened by a right of way over the land? Are not their respective interests also worth less because of the existence of the right? (Incidentally, a right of way over a res nullius is not impossible. Who is in such case the "owner-debtor"?)

Now, for Ginossar's third "riddle". Having asserted that, as an encumbrancer (say, of a right of way) I have a special right or claim against an ascertained person, Ginossar must turn to the question how this right of mine differs from a purely personal right. What is it that makes this right of mine, albeit (according to Ginossar) an obligatory one, "real"? In the nether regions below "la propriété", why bother to distinguish-and how is one to distinguish-between real rights and personal rights, instead of lumping all such plebeian rights together as undifferentiated personal rights? Ginossar's answer is that the mark of a real right is that the duty which corresponds to it is also real. Here perhaps lies the innovating crux of the new system. And the duty is said to be "real" in that the obligor is identified not by name or by any personal quality or attribute or undertaking made by him, but solely through his ownership of the land. The only distinguishing feature of this type of obligation is that it arises propter rem.

Nevertheless, the crucial consideration remains that a servient owner, even where identified solely by his ownership, still cannot, as such, be subjected to a judgment in personam. Yet what is a personal right if it is not (to borrow a famous phrase) the hypostasis of a prophecy that a personal remedy could be obtained? And what is a personal duty if not the hypostatis of a prophecy that a personal decree would be imposed? Where a would-be "personal duty" is of a kind that cannot be enforced by a personal proceeding, there a personal duty could not have arisen. Incidentally, a useful contrast is furnished by considering that anyone, including the servient owner, can be subjected to personal remedies after he has interfered with (say) a right of way: here 
indeed the defendant has, by his tortious misconduct, incurred an obligation, and is answerable therefor not to the value of this or that item of his wealth, not to the forfeiture of a deodand, but with the generality of his assets.

Again, a personal duty which is said to be freely transmissible by the obligor (when he, acting without the obligee's consent, conveys his land to a third party) cannot be a personal obligation or duty: for duties can be substituted by novation, or remitted by law, but are not assignable as though they were choses in action-they are not rights or assets or things but the "other side" of rights or assets or things, "anti-rights". If an owner is liable as such, then it is his ownership that engages his liability, not a transfer from a predecessor in title. Can the latter save his successor from the liability? Can he, in this case, affect to transfer the land without the liability?

It is intriguing to know whether Ginossar would argue that an encumbrance expires where the servient owner disappears without a trace in circumstances where the supposed "obligation" has no obligor to sustain it.

May I suggest that a clue to Ginossar's perplexity might be sought in the change of meaning that the idea of right undergoes when we move from obligatory to real rights. In the first context the word "right" stands for a claim, and must therefore have a duty to correspond to it. In the second context, "right" stands for a power or a liberty or an immunity (or a combination of such), and it does not require a corresponding obligation binding an ascertained person or persons. There is a duty in the narrow sense corresponding to every legal "claim", but not to every legal "right". What correspond to the latter are liabilities, disabilities and inabilities ("no-rights").

But what about that troublesome phenomenon, which looms large in Ginossar's thinking, of a "positive" or active servitude? Suppose that (be it by virtue of statute, custom, covenant, or otherwise) whoever is owner for the time being of a certain plot of land is bound to maintain a fence, which duty is enforceable at the suit of a neighbouring owner. Does it not, at least in this case, look as though we have discovered a "real obligation" which meets Professor Ginossar's specifications? This appears to be a very good example, because: (i) there is one individual, viz. the owner of the land, who in this case does indeed owe an active duty of "prestation" which is quite different from, and is additional to, the universal passive duty of noninterference, and (2) he owes this duty not because he has voluntarily undertaken it, nor because of any personal quality or attribute that he may have, but solely propter rem. It may, indeed, at first sight look like a "real obligation".

The circumstance, however, that an obligation rests on someone not because he has undertaken but because he stands in a special position to a res is no more incompatible with that obligation being "personal" than is the case with an obligation (e.g., of maintenance) imposed on one not because he has undertaken but because he is specially related to a person. Not all obligations arise $e x$ contractu: there are also obligations $e x$ lege. The liability of a landholder for property taxes may arise propter rem, but even then need not be 
intra rem; it may well extend over the entirety of his assets. Furthermore, tax liability in respect of a past period need not follow the land into the hands of a subsequent acquirer.

We may, for the sake of the argument, pass over the objection that, at least normally, a person does not acquire ownership of land unless he wants to, so that the supposition that the owner has not voluntarily undertaken the "active" duty should be understood sub modo. Even so, I suggest that this case, too, raises no difficulty within the traditional doctrine. The most fruitful way of comprehending this situation is to look at it, in the first place, from the angle of procedure or remedy. If, indeed, the owner is under duty to have the fence repaired, then he should be suable for a judgment in personam, as for a mandatory injunction or for damages or for both. It will be noted that only by a proceeding in personam can the aggrieved neighbour ultimately vindicate his protected interest (i.e., his right) to have the fence repaired by the adjoining servient owner. This can be tested as follows. Let us assume that there exists somewhere a system of civil procedure whereby it is possible, upon breach of the duty to repair, to institute a proceeding not in personam but only in rem. The land could eventually be seized and sold in satisfaction of the claim. Such a proceeding, however, would not be a technique adequate to the assumed right, because (among other considerations) the land may be worth less than the liability, while the debtor may be otherwise rich, i.e., it would not be such a remedy as would justify positing the assumed right. If this is the only sanction, there is a necessary feedback from its restricted nature to the right. The proceeding would also fail of its purpose where the land happened to be exempt from seizure and sale, as homestead or otherwise. If it is desired to have a name by which to describe the position of a person who is under no enforceable personal duty of prestation but from whom all or part of a thing may be lawfully taken, I suggest we may speak of "real liability". This is not, however, a real duty or obligation; and the difference between it and personal liability goes far beyond the method of ascertaining the debtor. Liability or exposure to eminent domain does not make all landholders obligors of the State.

The question can be tested not only from the procedural or litigious angle. Taking the obligation to repair a fence, one may also ask: can the obligation be defeated or affected through the obligor's misconduct or through events which happen to him? Where the answer is in the affirmative, the claim depends on the person of the obligor, is obligatory; and if the claim is obligatory, so is the duty; and there is no "real obligation". Consider what happens to the right where the "fence repairing" land passes into the hands of an owner who enjoys diplomatic immunity (or, indeed, where the present owner becomes entitled to immunity) or vanishes or is incapacitated or impecunious. You cannot make him repair the fence. But if you had a servitude of wayclearly not an obligatory right-you would go on having that right. Why? 
Because that right is not a claim on him, or on any other ascertained individual; is truly a right "in rem" in the one important sense of this manyfaceted expression, viz. a right not "in personam".

My response can be recapitulated. Ginossar's theory involves, or consists of, the following propositions:

1. Obligatory rights are all but "real". This position is achieved by focussing on the universal protection accorded such rights, to the neglect of their essential content as claims from ascertained obligors.

2. Encumbrances and other real rights "short of ownership" are, in effect, obligations because (according to Ginossar) they "bind" a determinate individual, the servient tenant, similarly to a personal obligation which binds a determinate obligor. This position is achieved by miscasting a victim (say, of a right of way) in the role of a debtor.

3. The servient tenant (particularly in those cases where he is under a positive duty of "doing") owes a "real obligation". This position is achieved by focussing on the origin of the duty as (capable of) arising propter rem, again to the neglect of its content and the methods of enforcement appropriate to it. And it is the supposition that there is an "obligation" on the servient tenant that necessitates the explanation that this supposed "obligation", being "real", is, unlike all "other" obligations, transmissible by the debtor acting unilaterally, i.e. conveying his land to a third party.

Ginossar's treatment forces rights and duties through a revolving door. Obligatory claims emerge, as it were, invigorated, looking like real rights; while real rights come out enfeebled, somewhat sheepishly, as obligatory claims. Above this turbulent process hovers uncertainly the "ownership itself" -obviously more important than any of the other rights discussed-yet, in terms of the new classification, curiously proclaimed to be neither fish nor fowl.

A. V. Levontin*

* Fisher Professor of Private International and Interreligious Law, The Hebrew University of Jerusalem. 